DOI: $10.33067 /$ SE.4.2021.6

Fustyna Godlewska-Szyrkowa *

\title{
EU Legal Migration Policy: Are There Prospects for Progress or Is It at a Standstill?
}

\begin{abstract}
The aim of the article is to attempt to identify the state of, and prospects for, the development of the common policy of the European Union regarding legal migration from third countries. The subject of interest is, above all, legal economic migration, which is crucial from the perspective of certain demographic processes taking place in the EU, the changes and needs of the Community's labour market, and the challenges posed by the digital transformation. The adopted hypothesis assumes that, within the framework of EU migration and asylum policy, policy as regards legal economic migration is still an underdeveloped area and remains in the hands of individual Member States. Initiatives undertaken in this area remain overshadowed by the main focus of the common migration and asylum policy, namely the development of a common asylum system and the prevention of irregular migration. Policy regarding legal economic migration in the near future will mainly be created by Member States and play out on the domestic stage due to the lack of direct motivation for its development at the Community level. In this case, the strength of particular stakeholders' interests is not balanced out by any direct and easily identifiable benefits to be gained from the adopted common solutions.
\end{abstract}

Keywords: European Union, Migration, Migration Policy, Legal Migration, Economic Migration

\section{Introduction}

As a coherent project and one of the policies of the European Union, the common migration and asylum policy has been developing for

^ Justyna Godlewska-Szyrkowa - University of Warsaw, e-mail: j.godlewska@ uw.edu.pl, ORCID: 0000-0002-7096-7351. 
over twenty years. ${ }^{1}$ The turning point here is seen as the moment the Amsterdam Treaty entered into force in 1999 and the act of transferring immigration and asylum matters from the third to the first pillar of the European Union, which meant the initiation of community solutions in this area. ${ }^{2}$ Creating a common policy in an area so strongly related to the prerogatives of the state, and strongly touching on the issue of security, is a task laden with a large dose of political risk. Indeed, one must admit that Adam Luedtke was right when he stated that "European migration policy harmonization is indeed exceptional, as it represents the first time in history that a group of democracies has pooled sovereignty to regulate the flow of persons". ${ }^{3}$

At the same time, since the initiation of this process, we have been dealing with different paces of development (and to different degrees) in various sectors of the common migration and asylum policy. Key areas for the common policy project aimed at external migratory movements ${ }^{4}$ are as follows: the Common European Asylum System, irregular migration, the return and readmission policy, legal migration, and immigrant integration. A special place is occupied by the free movement of persons within the Schengen Area, along with the common visa policy, which can be treated as a separate project which is a link between the internal ${ }^{5}$ and the external dimension of migration policy. The reasons for the divergence in the pace of development of individual elements of the common migration and asylum policy should be sought primarily in the different degrees at which Community solutions function in these areas. In other words, this hypothesis assumes that certain specific policies in the field of migration and asylum policy, due to their specific nature, are more will-

1 In accordance with Article 67 paragraph 2 of the Consolidated version of the Treaty on the Functioning of the European Union, The Union "shall ensure the absence of internal border controls for persons and shall frame a common policy on asylum, immigration and external border control, based on solidarity between Member States, which is fair towards third-country nationals".

2 J. Balicki, P. Stalker, Polityka imigracyjna i azylowa. Wyzwania $i$ dylematy, Wydawnictwo Uniwersytetu Kardynała Stefana Wyszyńskiego, Warsaw 2006, pp. 184-185. For more on the development of a common migration EU policy, see also: A. Luedtke, Migration governance in Europe: a historical perspective, in: The Routledge handbook of the politics of migration in Europe, eds. A. Weinar, S. Bonjour, L. Zhyznomirska, Routledge, Abingdon, Oxon, New York 2019, pp. 15-25, DOI: https://doi. org/10.4324/9781315512853-2; M. Pacek, M. Bonikowska, Unijna droga do wspólnej polityki migracyjnej w kontekście debaty o przyszłości Wspólnot, "Studia Europejskie", no. $1 / 2007$.

3 A. Luedtke, op.cit., p. 23.

${ }^{4}$ External migratory and refugee flows of non-EU nationals.

${ }^{5}$ Here understood as intra-EU migration flows. 
ingly implemented as community projects, while others clearly remain primarily in the hands of the Member States, and their development at the EU level is very difficult or else is inhibited.

This would mean that the project to enact a common migration and asylum policy is undergoing a two-speed development. ${ }^{6}$ On the one hand, there are areas that are relatively easily dealt with via common solutions, policies such as: visa policy (within the Schengen Area), asylum policy, return and readmission policy, and common border protection policy. These constitute the more developed part of the common migration and asylum policy. At the other extreme, there will therefore be specific policies which remain, to the greatest extent, the domain of the Member States: here we should point to the policy towards legal labour migration and the policy of integrating immigrants. It should be emphasised, however, that despite these very significant internal differences, the project to implement a common migration and asylum policy should be treated as a coherent whole, as its individual elements are interdependent, complementary and result in synergy.

This article focuses on producing an assessment of the state of, and prospects for, the development of a common policy on legal labour migration as potentially one of the key policies within the common migration policy of the European Union, the former common policy being one that, at the same time, has been developing slowly and with great difficulty.

\section{Framework for the Development of a Common EU Policy on Legal Labour Migration}

The legal and political frameworks defining the area, depth and potential direction of Community solutions are vitally important for the development of a common EU policy towards legal labour migration from third countries. According to Article 79 Par. 1 of the Treaty on the Functioning of the European Union, "The Union shall develop a common immigration policy aimed at ensuring, at all stages, the efficient management of migration flows, fair treatment of third-country nationals residing legally in Member States, and the prevention of, and enhanced measures to combat, illegal immigration and trafficking in human beings". This provision (and in particular the reference to "common immigration policy") can be

6 The hypothesis of the divergence in the speed of development of specific migration and asylum policies as part of the process of creating a common EU immigration and asylum policy was put forward by me and examined in an unpublished doctoral dissertation, see: J. Godlewska, Polityka imigracyjna państw Unii Europejskiej w ujęciu porównawczym, unpublished PhD thesis, Warsaw 2008, pp. 5-6. 
indirectly interpreted as providing the basis for developing a common approach to managing the inflow of economic migrants from outside the European Union. However, as Ferran Camas Roda notes, there is no direct reference in the Treaty to a common EU policy on economic migration. ${ }^{7}$ Nevertheless, the treaty's imposition of a limit within the regulations (on the Community level) regarding the number of economic migrants from third countries is also important, as it is thus guaranteed that this competence will remain within the remit of the individual Member States. ${ }^{8}$ Such a duality in the adopted solution indicates a high degree of caution in formulating the principles of a common policy towards legal labour migration and the desire to reassure Member States that their particular interests will be suitably protected here. Based on the provisions of the treaties, it can be stated that the development of a common policy towards legal migration from third countries, including economic migration, is to be implemented primarily by setting common rules defining the possibility of third-country nationals entering, and staying in, the EU. ${ }^{9}$

It is worth emphasizing that from the very beginning of the first decade of the 21st century, shortly after the Amsterdam Treaty entered into force, the first attempts were made within the EU to adopt common regulations relating to economic migration flows from third countries. In 2001, the European Commission proposed a draft of a directive on the conditions for entry and residence of third-country nationals for the purpose of employment and business activities, providing for the introduction of a uniform procedure for admitting such persons throughout the Community, ${ }^{10}$ which, however, was not finally adopted. This can be considered to indicate a lack of will at the time on the part of the Member States to develop

7 F.C. Roda, The approach of the European Union towards economic immigration for work purposes, "Revue de droit comparé du travail et de la sécurité sociale" [Online], no. 4/2019, p. 66, DOI: https://doi.org/10.4000/rdctss.1336.

8 Article 79 Paragraph 5 of the Treaty on the Functioning of the European Union states that "This Article shall not affect the right of Member States to determine volumes of admission of third-country nationals coming from third countries to their territory in order to seek work, whether employed or self-employed".

9 See: A. Kałabunowska, Polityka migracyjna $i$ azylowa Unii Europejskiej w kontekście kryzysu migracyjnego, "IZ Policy Papers", no. 34/2020, p. 18, https://www. researchgate.net/profile/Agata-Kalabunowska/publication/349494380_IZ_Policy_ Papers_nr_34_-_Polityka_migracyjna_i_azylowa_Unii_Europejskiej_w_kontekscie_kryzysu_migracyjnego/links/60338955ba6fdcc37a842b96e/IZ-Policy-Papers-nr34-Polityka-migracyjna-i-azylowa-Unii-Europejskiej-w-kontekscie-kryzysu-migracyjnego.pdf (access 19.07.2021).

10 Proposal for a Council directive on the conditions of entry and residence of third country nationals for the purpose of paid employment and self-employed economic activities, $\operatorname{COM(2001)} 386$ final, OJ C 332E, 27th Nov. 2001. 
a uniform, comprehensive approach to managing legal labour migration. ${ }^{11}$ Despite the failure of this draft, the issue of a common policy towards legal labour migration was raised again in the following years by the European Commission, in particular in its "Green Paper on an EU approach to managing economic migration". ${ }^{12}$ This document presents the key dilemmas related to creating a common policy in this area. It is worth noting, above all, the choice between the horizontal approach (common regulations relating to the admission of economic migrants from third countries, without distinguishing individual groups) and the sectoral approach (separate regulations for individual categories of economic migrants) ${ }^{13}$ within the community approach. Another important element consisted in directly defining the reasons why a common policy towards legal labour migration is important for the European Union. Among other things, such issues as the consequences of demographic changes in Member States for the economy and labour market of the Community (aging societies and the need to fill gaps in the labour supply), the need to increase international competitiveness, the impact of the solutions adopted in given countries on the situation in the entire European Union (due to the lack of internal borders), as well as the potential impact of the lack of Community solutions - in the field of legal routes to enter the EU labour market - on the increase in irregular migration. ${ }^{14}$ It should be noted that this was the first such loud voice within the EU to indicate the need to develop a common policy towards labour migration, encouraging a debate on this subject, and at the same time directly showing what challenges would be faced in this area. Ultimately, it was decided to build EU policy in the spirit of a sectoral approach and separately regulate the entry and residence of various categories of economic migrants. ${ }^{15}$

The acquis communautaire, which can be directly related to the formulation of the EU policy towards the influx of migrant workers from third countries, includes mainly a package of four directives ${ }^{16}$ adopted

11 See: J. Godlewska, op.cit., pp. 119-120.

12 Green Paper on the EU's approach to managing economic migration, $\operatorname{COM}(2004) 811$ final, Brussels, 11th Jan. 2005.

13 Ibidem, p. 5.

${ }^{14}$ Ibidem, pp. 3-4.; See also: J. Godlewska, op.cit., pp. 122-123.

15 See: criticism of the sectoral approach to legal labour migration: F.C. Roda, op.cit., pp. 68-72.

16 When considering a common policy towards legal migration from third countries in a broader perspective, including non-profit influences, the directives relating to family reunification should also be taken into account (2003): Council Directive 2003/86/EC of 22nd September 2003 on the right to family reunification, OJ L 251, 3rd Oct. 2003; long-term EU resident status: Council Directive 2003/109/EC of 25th 
over the last dozen or so years. In this way, the European Union decided to address issues such as: entry and residence conditions for highly skilled workers (EU Blue Card, 2009), ${ }^{17}$ the procedure for applying for a residence and work permit in one application (2011), ${ }^{18}$ conditions of entry and stay for seasonal workers (2014), ${ }^{19}$ and conditions of entry and stay for intra-corporate transferees (2014). ${ }^{20}$ The process of implementing all directives relating directly to the legal inflow of third-country nationals to the European Union was extremely varied, both in terms of time and content, and in the years 2018-2019 it was subject to internal and external evaluation, taking into account criteria such as: "relevance, coherence, effectiveness, efficiency and EU added value". ${ }^{21}$

As far as the objectives of the adopted solutions in the area of common EU policy are concerned, it is worth looking at how the impact of the directive referred to as the EU Blue Card (regulating the conditions for entry and settlement of highly qualified workers) was assessed in the evaluation

November 2003 concerning the status of third-country nationals who are long-term residents, OJ L 16, 23.01.2004; entry and stay for broadly understood educational and research purposes (2016): Directive (EU) 2016/801 of the European Parliament and of the Council of 11 May 2016 on the conditions of entry and residence of third-country nationals for the purposes of research, studies, training, voluntary service, pupil exchange schemes or educational projects and au pairing, OJ L 132, 21.05.2016. For more on the EU acquis to date in this area see: R. Cholewiński, EU Legal Migration Policies since Tampere, and Their Relationship with International Standards and the UN Global Compact for Migration, in: 20 Year Anniversary of the Tampere Programme: Europeanisation Dynamics of the EU Area of Freedom, Security and Fustice, eds. S. Carrera, D. Curtin, A. Geddes, Florence, 2020, pp. 200-203, https://www.ceps.eu/download/publication/?id=27624\&pdf=MPCTampere-Programme-final.pdf (access 13.07.2021).

17 Council directive 2009/50/EC of 25th May 2009 on the conditions of entry and residence of third-country nationals for the purposes of highly qualified employment, OJ L 155, 18th June 2009.

18 Directive 2011/98/EU of the European Parliament and of the Council of 13th December 2011 on a single application procedure for a single permit for third-country nationals to reside and work in the territory of a Member State and on a common set of rights for third-country workers legally residing in a Member State, OJ L 343, 23rd Dec. 2011.

19 Directive 2014/36/EU of the European Parliament and of the Council of 26th February 2014 on the conditions of entry and stay of third-country nationals for the purpose of employment as seasonal workers, OJ L 94, 28th March 2014.

${ }^{20}$ Directive 2014/66/EU of the European Parliament and of the Council of 15 th May 2014 on the conditions of entry and residence of third-country nationals in the framework of an intra-corporate transfer, OJ L 157, 27th May 2014.

${ }_{21}$ Commission Staff Working Document Fitness Check on EU Legislation on legal migration, SWD(2019) 1055 final, Brussels, 29th March 2019, p. 8, https:// ec.europa.eu/home-affairs/system/files/2019-03/swd_2019-1055-staff-working-part1. pdf (access 28.10.2021). 
process. In particular, we will be interested in the assessment of its impact on the development of the Community labour market and the Community economy (the effectiveness criterion). It was with the adoption of this directive that the greatest hopes were attached to the creation of conditions for attracting highly qualified migrants from third countries, which could contribute to building a competitive advantage. Unfortunately, the conclusions of the evaluation study indicate that, due to the very small number of EU Blue Cards issued, "it is unlikely that the BCD has contributed to a significant extent to the boosting of competitiveness, economic growth and enhancing the knowledge economy". ${ }^{22}$ A similar lack of impact can also be found for another target, namely "to address labour shortages". ${ }^{23}$ On this basis, it can be concluded that the mechanism adopted within the European Union to aid the recruitment of highly qualified migrants from third countries has not worked so far, mainly due to its lack of uptake. This would mean that the Member States have been implementing this part of the migration policy on the basis of national strategies and solutions that take into account individual economic and societal interests. Reluctance to use Community mechanisms may be the result of either a lack of motivation, due to the fact that national systems are perceived as sufficient, or the failure to adapt the adopted rules, and tools, to the real needs of the Member States. Either way, it seems the EU Blue Card essentially remains dead in the water. A question arises, therefore, as to what prospects exist for the future development of a common EU policy towards legal labour migration from third countries. Can we expect activities in this area to pick up, or is it a project that will play second fiddle to interest in policies aimed at managing refugee flows and protecting shared external borders? In order to try to answer this question, it would be good to cast an eye over one of the key current documents relating to the development plans of the EU's common migration and asylum policy.

\section{New Pact on Migration and Asylum}

Proposed by the European Commission in September 2020, the New Pact on Migration and Asylum ${ }^{24}$ defines the framework of a strategy with-

${ }^{22}$ Legal Migration Fitness Check Final Evaluation Report: Supporting study, Luxembourg: Publications Office of the European Union, 2019, p. 307, https://ec.europa. eu/home-affairs/system/files/2019-03/main-evaluation-report-supporting-studyicf_201806.pdf (access 30.11.2021).

${ }^{23}$ Ibidem.

${ }^{24}$ Communication from the Commission on a New Pact on Migration and Asy-

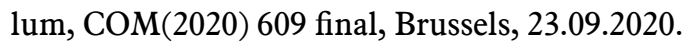


in which it is proposed to build a common EU migration policy in the coming years. The presented document clearly bears the imprint of the refugee crisis that affected the Union in 2015-2016 and its consequences for European integration. Challenges related to building and reforming the Common European Asylum System and ensuring conditions for effectively counteracting illegal migration take centre stage. Much space is devoted to issues of shared responsibility and the sharing of burdens related to migratory flows, in particular with regard to dealing with those applying for international protection, as well as mutual solidarity between Member States. The presented narrative shows an awareness of the consequences, over recent years, for European Union integration processes caused by the problems with finding a uniform and comprehensive response to irregular, mixed, migration-and-refugee inflows from third countries. It has also highlighted the need to better coordinate national efforts with the mechanisms adopted at the Community level, while at the same time building trust between Member States within the framework of a common migration and asylum policy. Between the lines, one can observe concern regarding separatist tendencies and an undermining of the community of interests within the EU. Indeed, it is expressly stated that "no Member State should shoulder a disproportionate responsibility and that all Member States should contribute to solidarity on a constant basis". ${ }^{25}$ Much space was also devoted to the need to develop common mechanisms to respond rapidly to crisis situations caused by uncontrolled migration flows, which is undoubtedly a by-product of the difficult experiences of recent years.

The issue of a common policy towards legal labour migration was mainly dealt with in the penultimate, seventh point of the document, entitled "Attracting skills and talent to the EU". ${ }^{26}$ The starting point is a diagnosis that has been known about for a long time and has been cited many times, one that points out the significant benefits that the Community and individual Member States may derive from controlled economic migration, primarily with regard to supplementing labour shortages in the labour market connected to the ageing of European societies. At the same time, the Commission's communication honestly admits that the European Union is not making proper use of its capabilities in this area and, as a result, "is currently losing the global race for talent". ${ }^{27}$ The remedy for this situation is intended to be a strengthening of the common migration policy, complementary to the solutions now functioning in the Member States and providing significant added value.

25 Ibidem, p. 2.

${ }^{26}$ Ibidem, pp. 24-26.

27 Ibidem, p. 25. 
The Commission's main focus here is to give a boost to the instruments that are already in place. Firstly, it has drawn attention to the need to conclude the negotiation process on the amended EU Blue Card directive, whose proposal was submitted by the European Parliament in $2016 .^{28}$ It should be noted that this recommendation has already been implemented and the new directive relating to "conditions of entry and residence of third-country nationals for the purpose of highly qualified employment" was adopted in October $2021 .{ }^{29}$ At this stage, it is difficult to assess the significance of the enhanced EU Blue Card, as everything depends on the way the directive is transposed into the legal systems of the Member States and the actual use of this instrument in managing the external inflow of highly qualified workers. The solutions adopted in the directive stipulate that the issuance of the EU Blue Card (a residence permit, valid for at least 24 months and allowing its holder to live and work in an EU Member State) will depend, among other things, on obtaining a job offer that requires high qualifications and is appropriately well-paid. Having this document facilitates the possibility of family reunification and obtaining long-term EU resident status. Importantly, the EU Blue Card enables (under certain conditions) short and long-term work mobility among Member States, mobility related to working in a profession requiring high qualifications. When comparing the 2009 and 2021 Directives, it can be stated that the most important differences between them concern, in the amended document, the flexibility and simplification of the conditions for the admission, residence and work of highly qualified workers from third countries, with a substantially similar structure of the solution itself and the instruments used. In principle, this may contribute to increasing the attractiveness of the EU Blue Card both for employers and migrants themselves, and to popularise this tool as an important element of the EU's common migration policy. On the other hand, it is difficult to unequivocally assess what effect the amended directive will have; memories of the failure of the directive in the not-so-different version of 2009 pour cold water on any high expectations and discourage overly bold predictions.

${ }^{28}$ Proposal for a directive of the European Parliament and of the Council on the conditions of entry and residence of third-country nationals for the purposes of highly skilled employment, $\operatorname{COM(2016)} 378$ final, Strasbourg, 07.06.2016.

${ }_{29}$ Directive (EU) 2021/1883 of the European Parliament and of the Council of 20 October 2021 on the conditions of entry and residence of third-country nationals for the purpose of highly qualified employment, and repealing Council Directive 2009/50/EC, OJ L 382, 28.10.2021. The previous EU Blue Card Directive of 2009 will expire on November 19, 2023. 
This part of the New Pact on Migration and Asylum, in addition to emphasising the importance of the enhanced EU Blue Card, also highlights the need to derive greater benefits from the international mobility of researchers and students, both for talent acquisition and the effective use of available knowledge in ecological and digital processes of transforming the EU economy. ${ }^{30}$ The Commission has also suggested reviewing the solutions' functioning under the directives relating to the conditions of admitting economic migrants from third countries: the directive on long-term residents and the single permit directive (here the aim would be to strengthen the rights of long-term residents ${ }^{31}$ and to facilitate procedures related to entry and residence in the EU). Also noteworthy is its support for a new initiative, being pushed within the OECD, called the EU Talent Pool. This is "an EU-wide platform for international recruitment, through which skilled third-country nationals could express their interest in migrating to the EU, and could be identified by EU migration authorities and employers based on their needs". ${ }^{32}$ Unfortunately, only a very general mention is made in the document, without indicating any planned activities in this area.

For the development of a common approach to managing legal labour migration, the "external dimension" of this policy may be important, implemented as it is in cooperation with third countries. In the Pact, a lot of space is taken up by the issue of cooperation with the countries of origin of migrants and people seeking international protection, seeing it as an indispensable element of a comprehensive approach to the management of migration inflows. Developing channels for legal migration (regardless of its causes and purpose) is vital so as to counteract irregular migration and, at the same time, respect the interests of both sending and receiving countries. With regard to labour migration, the Commission has proposed developing so-called Talent Partnerships, which constitute a model of multidimensional cooperation with third countries, with the intention of building mobility schemes for work, study and training, but at the same time supporting the potential of the labour market and education in the countries of origin of migrants. ${ }^{33}$ This allows the initiative to be read as an

${ }^{30}$ Communication from the Commission on a New Pact on Migration and Asylum, op.cit., p. 25.

31 "The objective would be to create a true EU long-term residence status, in particular by strengthening the right of long-term residents to move and work in other Member States", Ibidem, p. 26.

${ }^{32}$ Ibidem.

33 It was stated in the Pact as follows: "The Partnerships would combine direct support for mobility schemes for work or training with capacity building in areas such as labour market or skills intelligence, vocational education and training, 
attempt to better control external mobility, which is assumed to be shortterm in nature and, above all, tailored to the needs of the Community.

To sum up, it can be stated that the vision of the future outlined by the European Commission in the New Pact on Migration and Asylum with regard to building a common policy on legal labour migration - is conservative and based primarily on the use of existing instruments. New initiatives, such as, for example, Talent Partnerships, still function here primarily as certain ideas that need to be developed and operationalised.

\section{Conclusions}

What is the position of the policy on legal labour migration in the entirety of the solutions defined as the common EU migration and asylum policy? What are its prospects for future development? When answering these questions, one should distinguish between the declarative sphere and actual activities. In the former, the policy is one of the priorities in the development of a common migration policy. It is emphasised that, faced with many contemporary challenges for the economies of the Member States, their labour markets, and ongoing social changes, coherent EU mechanisms (that allow migration flows to be better managed and to be used for the development of the entire Community to the full) are extremely desirable and even indispensable. It would follow that Member States should be keenly interested in the dynamic development of this dimension of the common migration policy, and prospects for progress in this area would be an obvious consequence of these assumptions.

However, when we look at the actual actions taken by the European Union, it is clear that the common migration policy first and foremost still means a common asylum policy, a policy to protect external borders, and counteracting illegal migration. The area of legal labour migration remains the domain of Member States. This direction in the development of the migration policy even seems to have strengthened over the last few years, which is probably the result of the severe impact of the refugee crisis on arrangements regarding the adopted priorities for Community actions. The threat of uncontrolled migration and refugee inflows is easily iden-

integration of returning migrants, and diaspora mobilisation. Greater focus on education would help to support and reinforce investment in local skills", Ibidem, p. 23. The first pilot projects in this area have been going on since 2019; See: conclusions from their functioning so far: D. Stefanescu, Partnerships for Mobility at the Crossroads. Lessons Learnt From 18 Months of Implementation of EU Pilot Projects on Legal Migration, Brussels 2019, https://www.migrationpartnershipfacility.eu/storage/ files/mpf-policy-brief-pilot-projects-1020.pdf (access 12.12.2021). 
tifiable, and Member States have had the opportunity on more than one occasion to see that it is difficult to deal with it on their own. This means a potentially strong incentive to develop a common response with easily identifiable benefits from such collaboration. In the case of the policy towards legal economic migration, the picture is different. Member States have enjoyed varying success in developing national systems for managing the influx of economic migrants from third countries. Strengthening the Community framework in this area would require strong incentives which, at present, do not exist. The direct perception by Member States of possible negative consequences of the underdevelopment of this policy at the Community level is a matter affecting the distant, rather than the near, future, as is the impact of the potential benefits of its development. All of this inhibits the process of creating a common policy and is also visible in the lack of a new, holistic approach that could boost discussions on solutions in this area. The European Commission, in turn, acting as the main inspiration behind building a community approach, either points to already existing - but at the same time - conservative solutions, or tries to implement some new ideas in a rather general way, but without translating them into specific proposed of solutions. This means that, currently, we are left at a standstill when it comes to building a common system of economic migration management, and the prospects for changing this state of affairs are uncertain.

\section{References}

Balicki J., Stalker P., Polityka imigracyjna $i$ azylowa. Wyzwania $i$ dylematy, Cardinal Stefan Wyszyński University Press, Warsaw 2006.

Cholewiński R., EU Legal Migration Policies since Tampere, and Their Relationship with International Standards and the UN Global Compact for Migration, in: 20 Year Anniversary of the Tampere Programme: Europeanisation Dynamics of the EU Area of Freedom, Security and Fustice, eds. S. Carrera, D. Curtin, A. Geddes, European University Institute, Florence, 2020, https://www.ceps.eu/download/publication/?id=27624\&pdf $=$ MPCTampere-Programme-final.pdf (access 13.07.2021).

Commission Staff Working Document Fitness Check on EU Legislation on legal migration, SWD(2019) 1055 final, Brussels, 29.03.2019, https:// ec.europa.eu/home-affairs/system/files/2019-03/swd_2019-1055-staffworking-part1.pdf (access 28.10.2021).

Communication from the Commission on a New Pact on Migration and Asylum, COM(2020) 609 final, Brussels, 23.09.2020.

Consolidated versions of the Treaty on European Union and the Treaty on 
the Functioning of the European Union, 2012/C 326/01.

Council Directive 2003/86/EC of 22 September 2003 on the right to family reunification, OJ L 251, 3.10.2003.

Council Directive 2003/109/EC of 25 November 2003 concerning the status of third-country nationals who are long-term residents, OJ L 16, 23.01.2004.

Council Directive 2009/50/EC of 25 May 2009 on the conditions of entry and residence of third-country nationals for the purposes of highly qualified employment, OJ L 155, 18.06.2009.

Directive 2011/98/EU of the European Parliament and of the Council of 13 December 2011 on a single application procedure for a single permit for third-country nationals to reside and work in the territory of a Member State and on a common set of rights for third-country workers legally residing in a Member State, OJ L 343, 23.12.2011.

Directive 2014/36/EU of the European Parliament and of the Council of 26 February 2014 on the conditions of entry and stay of third-country nationals for the purpose of employment as seasonal workers, OJ L 94, 28.03.2014.

Directive 2014/66/EU of the European Parliament and of the Council of 15 May 2014 on the conditions of entry and residence of third-country nationals in the framework of an intra-corporate transfer, OJ L 157, 27.05.2014.

Directive (EU) 2016/801 of the European Parliament and of the Council of 11 May 2016 on the conditions of entry and residence of third-country nationals for the purposes of research, studies, training, voluntary service, pupil exchange schemes or educational projects and au pairing, OJ L 132, 21.05.2016.

Directive (EU) 2021/1883 of the European Parliament and of the Council of 20 October 2021 on the conditions of entry and residence of thirdcountry nationals for the purpose of highly qualified employment, and repealing Council Directive 2009/50/EC, OJ L 382, 28.10.2021.

Godlewska J., Polityka imigracyjna państw Unii Europejskiej w ujęciu porównawczym (unpublished $\mathrm{PhD}$ thesis), Faculty of Journalism and Political Science, University of Warsaw, Warsaw 2008.

Green Paper on an EU approach to managing economic migration, COM(2004) 811 final, Brussels, 11.01.2005.

Kałabunowska A., Polityka migracyjna $i$ azylowa Unii Europejskiej w kontekście kryzysu migracyjnego, "IZ Policy Papers", no. 34/2020, p. 18, https://www.researchgate.net/profile/Agata-Kalabunowska/ publication/349494380_IZ_Policy_Papers_nr_34_-_Polityka_ migracyina_i_azylowa_Unii_Europejskiej_w_kontekscie_kryzysu_ 
migracyjnego/links/6033895ba6fdcc37a842b96e/IZ-Policy-Papers-nr34-Polityka-migracyjna-i-azylowa-Unii-Europejskiej-w-konteksciekryzysu-migracyjnego.pdf (access 19.07.2021).

Legal Migration Fitness Check Final Evaluation Report: Supporting study, Publications Office of the European Union, Luxembourg, 2019, p. 307, https://ec.europa.eu/home-affairs/system/files/2019-03/ main-evaluation-report-supporting-study-icf_201806.pdf (access 30.11.2021).

Luedtke A., Migration governance in Europe: a historical perspective, in: The Routledge Handbook of Migration in Europe, eds. A. Weinar, S. Bonjour, L. Zhyznomirska, Routledge, Abingdon, Oxon, New York 2019, DOI: https://doi.org/10.4324/9781315512853-2.

Pacek M., Bonikowska M., Unijna droga do wspólnej polityki migracyjnej w kontekście debaty o przysztości Wspólnot, "Studia Europejskie", no. 1/2007.

Proposal for a Council directive on the conditions of entry and residence of third country nationals for the purpose of paid employment and self-employed economic activities, $\operatorname{COM}(2001) 386$ final, OJ C 332E, 27.11.2001.

Proposal for a directive of the European Parliament and of the Council on the conditions of entry and residence of third-country nationals for the purposes of highly skilled employment, $\operatorname{COM(2016)} 378$ final, Strasbourg, 07.06.2016.

Roda C.F., The approach of the European Union towards economic immigration for work purposes, "Revue de droit comparé du travail et de la sécurité sociale" [Online], no. 4/2019, DOI: https://doi.org/10.4000/ rdctss. 1336.

Stefanescu D., Partnerships for Mobility at the Crossroads. Lessons Learnt From 18 Months of Implementation of EU Pilot Projects on Legal Migration, International Centre for Migration Policy Development, Brussels 2019, https://www.migrationpartnershipfacility.eu/storage/files/mpfpolicy-brief-pilot-projects-1020.pdf (access 12.12.2021). 